\title{
MEASURING INNOVATION CULTURE: \\ A SYNTHESIS OF THE INNOVATION CULTURE CONSTRUCT AND IDENTIFICATION OF ITS RESEARCH CLUSTERS
}

\section{MEDICIÓN DE LA CULTURA DE LA INNOVACIÓN: UNA SÍNTESIS DEL CONSTRUCTO DE CULTURA DE INNOVACIÓN E IDENTIFICACIÓN DE SUS GRUPOS DE INVESTIGACIÓN}

\author{
Ricardo Garza ${ }^{\mathrm{a}}$ Alberto Lopez \\ Classification: Conceptual paper \\ Received: April 27, 2020 / Revised: May 30, 2020 \& June 24, 2020/ Accepted: June 25, 2020
}

\begin{abstract}
We provide an integrative review of the previous research that has measured the innovation culture construct. Our data reveal that the construct has been composed of 28 different dimensions in previous research. Furthermore, these dimensions can be graphed along two axes: presence of the dimension in the literature and importance of the dimension within every single research project in which it appears. This analysis shows that the dimensions can be integrated into a four-quadrant matrix: 1) core dimensions: those high in both importance and presence; 2) niche dimensions: those high in importance but relatively low in presence; 3) minor dimensions: those low in both importance and presence; and 4) generic dimensions: those low in importance but high in presence in the literature. Moreover, by conducting a multiple correspondence analysis along with cluster analysis, we can provide a detailed structure of the construct by revealing that scholars have measured innovation culture in seven fundamental different ways, through 1) employee characteristics, 2) external orientation and strategy, 3) internal communication, 4) collaboration, 5) willingness to change, 6) technology employed, and 7) adoption of new ideas. We finally provide a discussion section and suggest areas that have the greatest potential for future exploration in measuring the innovation culture construct.
\end{abstract}

Keywords: Innovation culture, research clusters, literature review, organisational management, innovation management.

\section{Resumen}

En este artículo proporcionamos una revisión integradora de la investigación previa que ha medido el constructo de la cultura de innovación. Nuestros datos revelan que el constructo se compone de 28 dimensiones diferentes. Además, estas dimensiones se pueden graficar a lo largo de dos ejes: presencia de la dimensión en la literatura e importancia de la dimensión dentro de cada proyecto de investigación en el que aparece. Este análisis muestra que las dimensiones pueden integrarse en una matriz de cuatro cuadrantes: 1) dimensiones centrales, que son altas en importancia y presencia; 2) dimensiones de nicho, aquellas de gran importancia, pero relativamente bajas en presencia; 3) dimensiones menores, las de baja importancia y presencia; y 4) dimensiones genéricas, de baja importancia, pero alta presencia en la literatura. Además, al realizar un análisis de correspondencia múltiple junto con un análisis de

Softtek, Monterrey, Mexico. Email: ricardo.garza@softtek.com

Tecnologico de Monterrey, Monterrey, Mexico. Email: alberto_lopez@tec.mx 
conglomerados, podemos identificar una estructura detallada del constructo al revelar que los investigadores han medido la cultura de innovación básicamente de siete maneras diferentes, a través de 1) características de los empleados, 2) orientación y estrategia externa, 3) comunicación interna, 4) colaboración, 5) disposición a cambiar, 6) tecnología empleada y 7) adopción de nuevas ideas. Finalmente proporcionamos una sección de discusión y sugerimos áreas de mayor potencial para futuras exploraciones en el dominio de medición del constructo de la cultura de innovación.

Palabras clave: cultura de innovación, grupos de investigación, revisión de literatura, comportamiento organizacional, gestión de innovación.

\section{Introduction}

Innovation is a key activity in the business world; several business leaders have stated that innovation is the most critical endeavour for businesses in order to create a sustainable competitive advantage (Chatzoglou \& Chatzoudes, 2018; Porter, 2008). Innovation is, therefore, one of the most influential drivers for the overall success of any organisation (Drucker, 1986). Innovation success is related to both external factors, such as consumer's perceptions (Schreier, Fuchs, \& Dahl, 2012), competition (Aghion et al., 2005), and sales growth (Coad \& Rao, 2008); internal factors, such as specialization, differentiation, communication, and slack of resources (Damanpour, 1991); employee's perceptions (Eisenberger, Fasolo, \& Davis-LaMastro, 1990); development in firm competence (Miozzo \& Ramirez, 2003); and even the creation of new business models (Webster \& Wing-Fai, 2017).

Previous research has found that one of the most important constructs driving innovation success is the level of innovation culture within a particular company (Ahmed, 1998; Martins \& Terblanche, 2003; NaranjoValencia, Jiménez-Jiménez, \& Sanz-Valle, 2011). This line of research concludes that the most innovative companies are those that have created appropriate cultures that propitiate innovation.

The construct of innovation culture has its origins in the overarching construct of organisational culture or culture of the factory, which was first coined back in 1951 (Jacques, 1951). This research domain has been a key concept in management research for several decades. One of the more widely used definitions is the one by Schein (1990):

Organisational culture can be defined as a pattern of basic assumptions, invented, discovered, or developed by a given group, as it learns to cope with its problems of external adaptation and internal integration, that has worked well enough to be considered valid and, therefore is to be taught to new members as the correct way to perceive, think, and feel in relation to those problems (p. 111).

In this paper, we build upon the organisational culture domain but focus on the nascent construct of innovation culture, which has been defined as "a multi-dimensional context which includes the intention to be innovative, the infrastructure to support innovation, operational level behaviours necessary to influence a market and value orientation, and the environment to implement innovation" (Dobni, 2008).

The seminal work of Dobni (2008) was actually the first one to point out the limitation of the lack of consensus regarding how to measure the level of innovation culture within a company. Based on this shortcoming, the author proposes a scale to measure this construct that has been more widely adopted by the academic community. However, there have been several further attempts to measure innovation culture. These attempts vary in number, type, and nature of their dimensions, indicating that the theorization of the construct of innovation culture remains nascent (Edmondson \& Mcmanus, 2007). In order to move research forward and make the theory more mature, it is necessary to have consent regarding how to measure this construct. In doing so, researchers can conduct more reliable and valid quantitative research and actually test hypotheses regarding the innovation culture within a company.

Due to this lack of agreement on how to objectively measure the level of innovation culture within a company, we aim to conduct an integrative literature research of the different ways that the innovation culture construct has been measured in previous literature. We clarify that we are not going to offer a literature review on the topic of innovation culture (for this please see the work of Crossan and Apaydin, 2010). We, on the other hand, offer a review on the measurement of this construct: on how scholars have measured this construct in previous research.

In this paper, we conduct an exhaustive review of the literature regarding the measurement of the innovation culture within a company. According to previous research, we have identified 28 dimensions that make up this construct. We then provide a detailed definition of every one of these dimensions and graph them along two axes: presence of the dimension in previous literature and importance of the dimension in the papers it appears. This analysis shows that the dimensions can be visualized into a four-quadrant matrix: core, niche, generic, and minor dimensions. 
Our paper is structured as follows: We start by presenting a review of the relevant literature regarding the innovation culture in a company; then we proceed to show and explain the 28 different dimensions found. We then present empirical data from our literature review and graph the dimensions into two axes. Furthermore, by conducting a multiple correspondence analysis along with a cluster analysis, we can provide a detailed structure of the field by revealing that scholars have fundamentally measured innovation culture in seven different ways, by relying on 1) employee characteristics, 2) external orientation and strategy, 3) internal communication, 4) collaboration, 5) willingness to change, 6) technology employed, and 7) adoption of new ideas.

Finally, we suggest areas of greatest potential for future research. To the best of our knowledge, this is the first attempt to review the academic literature on the measurement of the innovation culture construct, and, therefore, this work makes a significant contribution to the field of both organisational culture and innovation management.

\section{Methodology}

As previously pointed out, the present paper starts by carrying out an extensive and systematic review of the previous literature on measuring innovation culture in a company. The purpose of this paper is also to organise the academic literature on this topic and to propose an integrative model that can exhaustively measure this construct.

Identifying the papers

In order to guarantee the validity of this review, we followed a systematic process. To gather the initial pool of papers, we conducted extensive searches in the top academic databases such as EBSCO Academic Search Ultimate and The Web of Science. We searched a large set of keywords, such as innovation culture, organisational innovation, and organisational innovativeness. Abstracts were then analysed to determine the fit with our research purpose. The main selection criteria was that the paper focused on the measurement of the innovation culture, not about the phenomenon in general, but mainly about the measurement of the construct. After several rounds of filtering, we selected 41 final papers that had the following criteria: 1) the paper was published in a peerreviewed journal, 2) the research mainly focuses on the measurement of the level of innovation culture in a company, and 3) the paper is entirely written in the English language. Table 1 shows the total number of published papers on the topic by each journal. It is interesting to note that while our review includes papers from more than 30 academic journals, only seven journals make up almost $50 \%$ of all published papers (European Journal of Innovation Management, Academy of Management Journal, Industrial Marketing Management, European Journal of Marketing, International Journal of Technology Management, Journal of Marketing, and Technological Forecasting and Social Change).

It is also interesting to note that the analysed papers range over a long period of time. Some published papers deal with the measurement of this construct before the $90 \mathrm{~s}$, and there are also more recent published papers; our literature review included papers published up to 2019. Overall, the articles are distributed homogeneously over time. Figure 1 shows a graph with the number of published papers on this topic by year.

Figure 1. Number of papers published per year

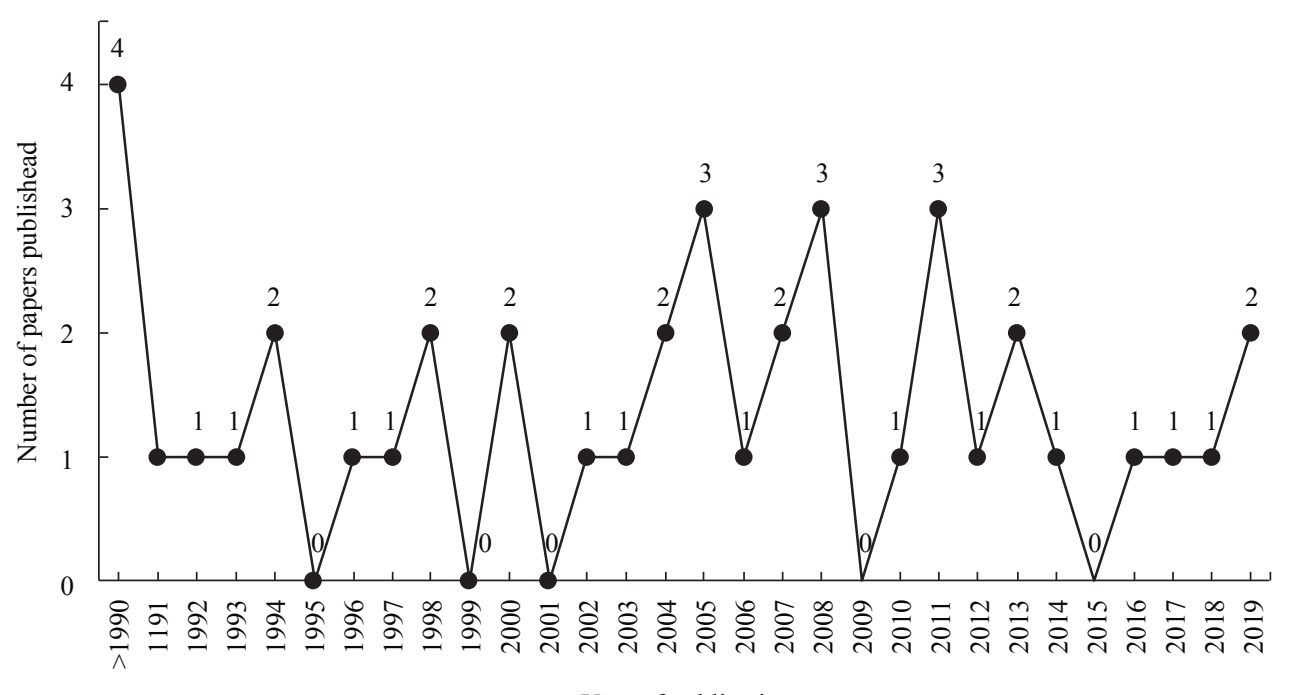

Year of publication 
Table 1. Number of published papers by Journal

\begin{tabular}{|c|c|}
\hline Journal & Papers Published \\
\hline European journal of innovation management & 4 \\
\hline Academy of management journal & 3 \\
\hline Industrial marketing management & 3 \\
\hline European Journal of Marketing & 2 \\
\hline Int Journal of Technology Management & 2 \\
\hline Journal of Marketing & 2 \\
\hline Technological Forecasting and Social Change & 2 \\
\hline Leadership \& Organisation Development J. & 1 \\
\hline Administrative science quarterly & 1 \\
\hline American political science review & 1 \\
\hline Creativity and Innovation Management & 1 \\
\hline Entrepreneurship: Theory and Practice & 1 \\
\hline Human Communication Research & 1 \\
\hline Int. journal of innovation management & 1 \\
\hline Journal of Communication Management & 1 \\
\hline Journal of evaluation in clinical practice & 1 \\
\hline Journal of product innovation management & 1 \\
\hline Knowledge and Process Management & 1 \\
\hline Management Science & 1 \\
\hline Omega & 1 \\
\hline Project Management Journal & 1 \\
\hline Quarterly Review of Distance Education & 1 \\
\hline Strategy \& Leadership & 1 \\
\hline The journal of creative behavior & 1 \\
\hline Transform & 1 \\
\hline Advances in Developing Human Resources & 1 \\
\hline RAI Revista de Administração e Inovação & 1 \\
\hline European Planning Studies & 1 \\
\hline Journal of Business Venturing Insights & 1 \\
\hline$R \& D$ Management & 1 \\
\hline Total & 41 \\
\hline
\end{tabular}

\section{Classifying the papers}

Each of the 41 papers previously identified was read in its entirety and then classified according to its definition and operationalization of the innovation culture construct. It is once again important to mention that the focus was on the measurement and operationalization of the innovation culture construct and not about the overall innovation culture phenomenon. The authors iteratively analysed the 41 papers (Spiggle, 1994); the papers were read several times to identify the different definitions and dimensions of the innovation culture constructs that they each included. The coding process was as follows: both authors independently coded each paper into the different dimensions that were operationalized in the construct. The authors finished analysing the data when they stopped seeing new dimensions emerging. After having coded their reviews independently, both raters met to discuss disagreement in their ratings and to find consensus. The raters reached $100 \%$ agreement after discussion. This coding was conducted with the aid of the software NVivo (version 11). Based on these results, we identified the main dimensions that comprise the construct of innovation culture and illustrated the state of the art regarding how it is measured.

\section{Emerging dimensions}

During the coding process, 28 different dimensions that make up the innovation culture within a company emerged from the data. Every one of the 41 papers was analysed, and the dimensions of the innovation culture were identified as previously explained. Some papers only included one dimension of the construct, while others included more than 10 . The average number of dimensions per paper was 4.78 , which supports the claim that the innovation culture construct is indeed multi-dimensional. Finally, 28 different dimensions were identified across all published papers. Table 2 shows a summary of the literature review conducted as well as the results from the coding analyses. It displays the 28 different dimensions with their corresponding theoretical references.

There are dimensions with great theoretical support. For example, strategic is the dimension with the most references (21), followed by behaviour (15), and management encouragement (15). Other dimensions that were found across many previous works are rewards system (12), communication (11), resources (11), market orientation (10), organisational learning (10), risk-taking (10), and autonomy (9).

Only ten dimensions with the highest repetition frequency across papers account for more than $60 \%$ of all frequencies, which offers empirical support for them.

Derived from our exhaustive theoretical revision, we provide a brief definition for every one of the 28 different dimensions. Table 3 shows these definitions, which were adapted from the literature listed in table 2.

\section{Presence and importance of the emerging dimensions}

In order to offer a visual representation of the 28 emerging dimensions, we plotted them along two axes: 1) degree of presence of the dimension and 2) degree of relative importance of the dimension. To do so, we operationalized the degree of presence as the number of papers 
Table 2. Dimensions of the Innovation culture construct

\begin{tabular}{|c|c|}
\hline Dimension & References \\
\hline 1. Autonomy & $\begin{array}{l}\text { (Ahmed, 1998; Damanpour, 1991; Dobni, 2008; Dombrowski et al., 2007; Martins \& Terblanche, 2003; McLaughlin, Bessant, } \\
\text { \& Smart, 2008; McLean, 2005; Martín-de Castro et al., 2013) }\end{array}$ \\
\hline 2. Behaviour & $\begin{array}{l}\text { (Apekey et al., 2011; Avlonitis, Kouremenos, \& Tzokas, 1994; Chandler, Keller, \& Lyon, 2000; Daft, 1978; Dobni, 2008; } \\
\text { Dombrowski et al., 2007; Hult, Hurley, \& Knight, 2004; Hurt, Joseph, \& Cook, 1977; Martín-de Castro et al., 2013; Martins \& } \\
\text { Terblanche, 2003; McLaughlin, Bessant, \& Smart, 2008; O’Cass \& Viet Ngo, 2007; Padilha \& Gomes, 2016; Scott \& Bruce, } \\
\text { 1994; Wang \& Ahmed, 2004) }\end{array}$ \\
\hline 3. Communication & $\begin{array}{l}\text { (Apekey et al., 2011; Damanpour, 1991; Dombrowski et al., 2007; Hurley \& Hult, 1998; } \\
\text { Jin, Navare, \& Lynch, 2019; Linke \& Zerfass, 2011; Martins \& Terblanche, 2003; } \\
\text { Michaelis, Aladin, \& Pollack, 2018; O’Cass \& Viet Ngo, 2007; Pallas et al., 2013; } \\
\text { Padilha \& Gomes, 2016) }\end{array}$ \\
\hline 4. Decision making & (Hurley \& Hult, 1998) (Olmos-Peñuela et al., 2017) \\
\hline 5. Failure acceptance & $\begin{array}{l}\text { (Ahmed, 1998; Auh \& Menguc, 2005; Jin, Navare, \& Lynch, 2019; Martins and Terblanche, 2003; Michaelis, Aladin, \& } \\
\text { Pollack, 2018; Scott \& Bruce, 1994) }\end{array}$ \\
\hline 6. First to market & (Capon et al., 1992; Deshpande, Farley, \& Webster, 1993) \\
\hline 7. Future orientation & (Ahmed, 1998; Arad, Hanson, \& Schneider, 1997; Brettel \& Cleven, 2011) \\
\hline $\begin{array}{l}\text { 8. Implementation of } \\
\text { an innovation }\end{array}$ & (Dobni, 2008; Olmos-Peñuela et al., 2017; Sharifirad \& Ataei, 2012) \\
\hline 9. Infrastructure & (Apekey et al., 2011; McLaughlin, Bessant, \& Smart, 2008;) \\
\hline $\begin{array}{l}\text { 10. Management } \\
\text { Encouragement }\end{array}$ & $\begin{array}{l}\text { (Ahmed, 1998; Apekey et al., 2011; Arad, Hanson, \& Schneider, 1997; Auh \& Menguc, 2005; Chandler, Keller \& Lyon, 2000; } \\
\text { Damanpour, 1991; Dombrowski et al., 2007; } \\
\text { Herzog, 2008; McLaughlin, Bessant, \& Smart, 2008; Martín-de Castro et al., 2013; McLean, 2005; Michaelis, Aladin, \& } \\
\text { Pollack, 2018; O'Cass \& Viet Ngo, 2007; Pallas et al., 2013; Scott \& Bruce, 1994) }\end{array}$ \\
\hline 11. Market orientation & $\begin{array}{l}\text { (Ahmed, 1998; Baldridge \& Burnham, 1975; Deshpande, Farley, \& Webster, 1993; } \\
\text { Dobni, 2008; Hult, Hurley, \& Knight, 2004; Hurley \& Hult, 1998; McLaughlin, Bessant, \& Smart, 2008; Sharifirad \& Ataei, } \\
\text { 2012; Siguaw, Simpson, \& Enz, 2006; Wang \& Ahmed, 2004) }\end{array}$ \\
\hline 12. NIH syndrome & (Herzog, 2008; Nestle et al., 2019) \\
\hline 13. Organisational structure & $\begin{array}{l}\text { (Arad, Hanson \& Schneider, 1997; Baldridge \& Burnham, 1975; Damanpour, 1991; Hurley \& Hult, 1998; O’Cass \& Viet Ngo, } \\
\text { 2007; McLaughlin, Bessant \& Smart, 2008; Michaelis, Aladin, \& Pollack, 2018; Padilha \& Gomes, 2016; Subramanian \& } \\
\text { Nilakanta, 1996) }\end{array}$ \\
\hline 14. Organisational learning & $\begin{array}{l}\text { (Ahmed, 1998; Arad, Hanson, \& Schneider, 1997; Brettel \& Cleven, 2011;Calantone, Cavusgil, \& Zhao, 2002; Dobni, 2008; } \\
\text { Hult, Hurle,y \& Knight, 2004;Hurley \& Hult, 1998; } \\
\text { Martins \& Terblanche, 2003; McLaughlin, Bessant, \& Smart, 2008; Siguaw, Simpson, \& Enz, 2006) }\end{array}$ \\
\hline 15. Personality traits & $\begin{array}{l}\text { (Ahmed, 1998; Baldridge and Burnham, 1975; Didero et al., 2008; Hurt, Joseph, \& Cook, 1977; Leavy, 2005; McLaughlin, } \\
\text { Bessant, \& Smart, 2008; Scott \& Bruce, 1994) }\end{array}$ \\
\hline 16. Process & $\begin{array}{l}\text { (Jin, Navare, \& Lynch, 2019; McLaughlin, Bessant, \& Smart, 2008; Michaelis, Aladin, \& Pollack, 2018; Siguaw, Simpson, \& } \\
\text { Enz, 2006; Unger, Rank, \& Gemünden, 2014; Wang and Ahmed, 2004) }\end{array}$ \\
\hline 17. Product & $\begin{array}{l}\text { (Ahmed, 2004; Calantone, Cavusgil, \& Zhao, 2002; Capon et al., 1992; Hurley \& Hult, 1998; Wang, McLaughlin, Bessant \& } \\
\text { Smart, 2008) }\end{array}$ \\
\hline $\begin{array}{l}\text { 18. Rate of adoption } \\
\text { of innovations }\end{array}$ & (Calantone, Cavusgil, and Zhao, 2002; Capon et al., 1992; Deshpande, Farley, \& Webster, 1993; Simonson, 2000) \\
\hline 19. Resources & $\begin{array}{l}\text { (Ahmed, 1998; Apekey et al., 2011; Damanpour, 1991; Martins \& Terblanche, 2003; McLaughlin, Bessant, \& Smart, 2008; } \\
\text { McLean, 2005; Mohr, 1969; Scott \& Bruce, 1994; Sharifirad \& Ataei, 2012; Siguaw, Simpson, \& Enz, 2006; Subramanian \& } \\
\text { Nilakanta, 1996) }\end{array}$ \\
\hline 20. Rewards system & $\begin{array}{l}\text { (Ahmed, 1998; Apekey et al., 2011; Arad, Hanson, \& Schneider, 1997; Chandler, Keller, \& Lyon, 2000; Dombrowski et al., } \\
\text { 2007; Jin, Navare \& Lynch, 2019; Martins \& Terblanche, 2003; Michaelis, Aladin, \& Pollack, 2018; Padilha \& Gomes, 2016; } \\
\text { Pallas et al., 2013; Unger, Rank, \& Gemünden, 2014) }\end{array}$ \\
\hline 21. Risk-taking & $\begin{array}{l}\text { (Ahmed, 1998; Apekey et al., 2011; Arad, Hanson, \& Schneider, 1997; Auh \& Menguc, 2005; Brettel \& Cleven, 2011; Herzog, } \\
\text { 2008; Hurley \& Hult, 1998; Jin, Navare, \& Lynch, 2019; Martins \& Terblanche, 2003; McLaughlin, Bessant, \& Smart, 2008) }\end{array}$ \\
\hline 22. Sharing & $\begin{array}{l}\text { (Arad, Hanson, \& Schneider, 1997; Hurley \& Hult, 1998; Dombrowski et al., 2007; Scott \& Bruce, 1994; Siguaw, Simpson, } \\
\text { \& Enz, 2006) }\end{array}$ \\
\hline 23. Strategic & $\begin{array}{l}\text { (Ahmed, 1998; Arad, Hanson, \& Schneider, 1997; Avlonitis, Kouremenos, \& Tzokas, 1994; Brettel \& Cleven, 2011; Chandler, } \\
\text { Keller, \& Lyon, 2000; Daft, 1978; Dobni, 2008; Apekey et al., 2011; Dombrowski et al., 2007; Hurt, Joseph, \& Cook, 1977; } \\
\text { Jin, Navare \& Lynch, 2019; Martín-de Castro et al., 2013; Martins \& Terblanche, 2003; McLaughlin, Bessant, \& Smart, 2008; } \\
\text { Michaelis, Aladin, \& Pollack, 2018; Padilha \& Gomes, 2016; Pallas et al., 2013; Sharifirad \& Ataei, 2012; Siguaw, Simpson, \& } \\
\text { Enz, 2006; Unger, Rank, \& Gemünden, 2014; Wang \& Ahmed, 2004) }\end{array}$ \\
\hline 24. Teamwork & $\begin{array}{l}\text { (Arad, Hanson, \& Schneider, 1997; Damanpour, 1991; Dombrowski et al., 2007; Hurley \& Hult, 1998; McLean, 2005; } \\
\text { Michaelis, Aladin, \& Pollack, 2018; Olmos-Peñuela et al., 2017; Scott \& Bruce, 1994) }\end{array}$ \\
\hline 25. Technology focus & (Auh \& Menguc, 2005; Siguaw, Simpson, \& Enz, 2006) \\
\hline 26. Value orientation & (Dobni, 2008) \\
\hline 27. Willingness to change & (Simonson, 2000) \\
\hline 28. Workload pressure & (Chandler, Keller, \& Lyon, 2000) \\
\hline
\end{tabular}


that contain a particular dimension multiplied by the number of citations of such papers. The median of papers in which a dimension appears multiplied by the number of citations of those papers is 58,467. Moreover, we operationalized the degree of importance as the average number of times a particular dimension appears in a paper; a more important dimension will be used more often in a single paper (total number of times a dimension appears in the data/number of articles in which it appears). On this axis, the median value is 22 mentions per paper. Plotting these two variables - presence and importance - and using median values as a cut-off (i.e., above-median and below-median presence and importance), we thus classify each of the 28 dimensions into one of four quadrants (see figure 2).

In order to count the number of times that a dimension was mentioned in a paper, we employed the word cruncher analysis tool in ATLAS.TI version 7.5. We converted all 41 articles into Word format and removed tables, figures, and references. To reduce ambiguity, we omitted methods sections because they tend to contain many statistical and methodological words. This resulted in approximately 550 pages of text. For the citations count, we relied on Google Scholar since it has been found that it finds nearly all citations found by WoS and Scopus (Martín-Martín et al., 2018). Results can be seen in figure 2. The lines that divide the plot into four quadrants are placed in the median value of every axis. We classified all 28 dimensions into one of four categories or quadrants, which will now discuss.

Core dimensions. This quadrant comprises nine dimensions (market orientation, strategic, organisational learning, behaviour, organisational structure, communication, resources, autonomy, and risk-taking), which all have a high presence and importance. These nine dimensions are the ones most commonly used in the literature; they represent the core dimensions of the innovation culture construct. Previous attempts to measure innovation culture have strongly relied on these nine dimensions.

Niche dimensions. This quadrant is made of five dimensions (first to market, future orientation, willingness to change, product, and rate of adoption). These dimensions are less frequently mentioned in the literature; however, they are highly mentioned within a smaller

Figure 2. Emerging dimensions by presence and importance

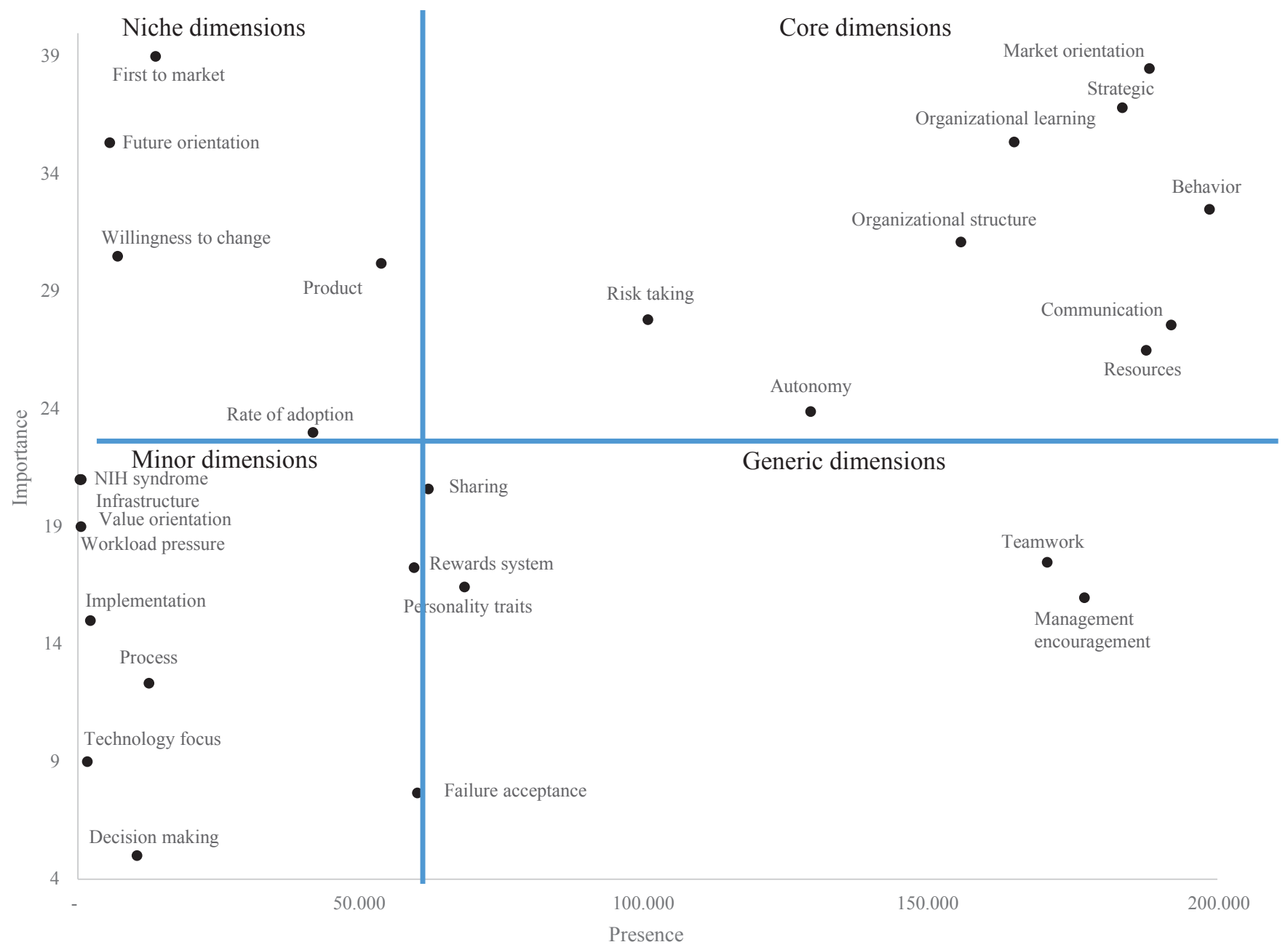


Table 3. Definitions of the dimensions of the Innovation culture construct

\begin{tabular}{|c|c|}
\hline Dimension & Definition \\
\hline 1. Autonomy & $\begin{array}{l}\text { The extent to which employees are granted freedom and the authority to make decisions and solve problems. Personnel, therefore, } \\
\text { have the freedom to do their work and determine procedures as they see fit within the guidelines provided. }\end{array}$ \\
\hline 2. Behaviour & $\begin{array}{l}\text { This reflects the "sustained behavioural change" of the organisation towards innovations - "behavioural commitment"; in other words } \\
\text { it is the behavioural disposition of firms to make use of technological innovations and stems from a direct account of the diffusion } \\
\text { process of innovations as a communication process. It delineates the commitment of firms to expose themselves to innovations. }\end{array}$ \\
\hline 3. Communication & $\begin{array}{l}\text { The degree to which tactics and explicit knowledge are widely gathered (both from within and outside the organisation), is easily } \\
\text { available, rapidly transmitted, and honestly communicated throughout the organisation. As no one can know in advance what } \\
\text { information may stimulate or aid an innovation, the degree to which knowledge is censored, filtered, or summarized by others detracts } \\
\text { from this dimension. }\end{array}$ \\
\hline 4. Decision making & Is the decision-making process centralized or decentralized? Do all individuals participate in decision making or only top management? \\
\hline 5. Failure acceptance & $\begin{array}{l}\text { How does the company face failure? Do managers accept failure and even understand it as positive? Is it seen as a way to learn from } \\
\text { mistakes? Or, are failures are highly discouraged and even punished? }\end{array}$ \\
\hline 6. First to market & Is the company the first to launch an innovation? Or, does it just follow what others do/launch? \\
\hline 7. Future orientation & $\begin{array}{l}\text { Does the company have a large scope of planning? Does it plan for the long-run? Or does the company only react to what is happening } \\
\text { right now or what will happen in the near or short-term? }\end{array}$ \\
\hline $\begin{array}{l}\text { 8. Implementation of } \\
\text { an innovation }\end{array}$ & $\begin{array}{l}\text { What is the environment or context to support the implementation of innovations like? Is it easy to implement an innovation? Or is it } \\
\text { a bureaucratic and discouraging process? }\end{array}$ \\
\hline 9. Infrastructure & Does the company provide an infrastructure to support innovation among the employees? \\
\hline $\begin{array}{l}\text { 10. Management } \\
\text { encouragement }\end{array}$ & $\begin{array}{l}\text { Does management support innovation? Do managers give "free time" to employees to innovate? Do they encourage it, give feedback, } \\
\text { and promote an environment that encourages innovation? }\end{array}$ \\
\hline 11. Market orientation & $\begin{array}{l}\text { Market orientation is widely known as an organisational culture that supports behaviours that dictate how employees think and act } \\
\text { as this relates to the implementation of the marketing concept. Key capabilities of a market orientation include things including } \\
\text { market sensing, customer linking, competitor sensing, and customer service. Other capabilities include technology development, new } \\
\text { product/service development, and organisational communication. }\end{array}$ \\
\hline 12. NIH syndrome & $\begin{array}{l}\text { The not-invented-here (NIH) syndrome generally denotes a negative attitude towards external technology sourcing. It represents the } \\
\text { negative effects resulting from an overemphasis on internal technologies, ideas, or knowledge. }\end{array}$ \\
\hline $\begin{array}{l}\text { 13. Organisational } \\
\text { structure }\end{array}$ & $\begin{array}{l}\text { This is an organisational structure where decisions are made by different people in the organisation, across levels and divisions. } \\
\text { Structural characteristics of the organisation, such as size and complexity strongly affect the organisation's innovative behaviour. }\end{array}$ \\
\hline $\begin{array}{l}\text { 14. Organisational } \\
\text { learning }\end{array}$ & $\begin{array}{l}\text { Organisational learning is associated with the development of new knowledge, which is crucial for firm innovation capability and firm } \\
\text { performance. An organisation committed to learning is likely to possess state-of-the-art technology, which leads to greater innovation } \\
\text { capability in both products and processes. }\end{array}$ \\
\hline 15. Personality traits & $\begin{array}{l}\text { Personality traits that have been identified with highly innovative people: creativity, diverse backgrounds, diverse employees, broad } \\
\text { interests, high energy, intuition, self-confidence, persistence, curiosity, energy, etc. }\end{array}$ \\
\hline 16. Process & $\begin{array}{l}\text { Business processes that facilitate the gathering and recording of ideas for future innovations. This emphasizes the concept that } \\
\text { gathering new ideas is a necessary part of day-to-day business operations. Does the company have internal innovative processes? Are } \\
\text { the internal and manufacturing processes are innovative? Do they support and encourage innovation? Are they bureaucratic? }\end{array}$ \\
\hline 17. Product & $\begin{array}{l}\text { Product innovativeness is most often referred to as perceived newness, novelty, originality, or uniqueness of products. It is the novelty } \\
\text { and meaningfulness of new products introduced to the market in a timely fashion. }\end{array}$ \\
\hline $\begin{array}{l}\text { 18. Rate of adoption } \\
\text { of innovations }\end{array}$ & Are innovations rapidly adopted by individuals? Is adoption encouraged? Are innovations promoted and communicated? \\
\hline 19. Resources & $\begin{array}{l}\text { Does the company give "financial" resources to employees to innovate? Does the company facilitate innovation by allowing enough } \\
\text { resources? }\end{array}$ \\
\hline 20. Rewards system & How is innovation rewarded? Are there reward systems for innovative individuals? Are there financial and non-financial incentives? \\
\hline 21. Risk-taking & How are risks taken? Is there a high or low risk aversion? \\
\hline 22. Sharing & $\begin{array}{l}\text { Do individuals share their knowledge with others? Or are they "jealous" about their knowledge? Do they share information, methods, } \\
\text { ideas...? }\end{array}$ \\
\hline 23. Strategic & $\begin{array}{l}\text { Is innovation driving the company's strategy? Is the premise of the business model based on strategic intent? Is the top management } \\
\text { able to effectively cascade the innovation message throughout the organisation? Is innovation part of the mission and vision of the } \\
\text { company? Is innovation part of the strategic planning of the company? }\end{array}$ \\
\hline 24. Teamwork & Do individuals work in teams? Is teamwork a core value among the company? \\
\hline 25. Technology focus & Is technology used to improve? Does the company develop and adopt technology as a tool to innovate? \\
\hline 26. Value orientation & $\begin{array}{l}\text { There is a consensus amongst employees about what creates value for customers/stakeholders: "I understand what systems/processes } \\
\text { we must excel at to deliver customers/stakeholder value". }\end{array}$ \\
\hline $\begin{array}{l}\text { 27. Willingness to } \\
\text { change }\end{array}$ & Are individuals willing to change? Is the company flexible enough to let changes occur? How is the organisational change process? \\
\hline 28. Workload pressure & Are individuals mentally able to innovate? Are they burnt out because of a high workload? \\
\hline
\end{tabular}


subset of papers, that is why they represent a niche. Previous attempts to measure innovation culture have not relied on these five dimensions that much; however, they are highly used in some papers, so we conclude they represent an important niche in the field.

Minor dimensions. This quadrant comprises eight dimensions (not invented here syndrome, infrastructure, value orientation, workload pressure, implementation, process, technology focus, and decision making). These eight dimensions are the ones less commonly used in the literature as they represent the minor dimensions of the innovation culture construct. Previous attempts to measure innovation culture have not relied much on these eight dimensions. Since they represent the least studied dimensions, we argue that they may be a good avenue for further enquiry.

Generic dimensions. This quadrant comprises six dimensions (teamwork, management encouragement, sharing, rewards system, personality traits, and failure acceptance). These dimensions are frequently mentioned in the literature but are relatively unimportant. They are mainly used in a generic sense.

\section{Identifying clusters}

Now that we have presented the emerging dimensions from our theoretical revision, we proceed to uncover the underlying clusters that group together these 28 dimensions. We conducted this analysis in order to identify how the 28 dimensions group together in the research field. We cannot expect that a single paper studies all 28 dimensions; therefore, we conducted this analysis in order to determine how researchers have mixed together the 28 dimensions in order to identify the main types of approaches that researchers have applied to measure a company's level of innovation culture. To reiterate, it is important to point out that we are specifically looking at how the innovation culture construct has been measured.

First, we conducted a multiple correspondence factor analysis with the total of 28 dimensions discovered in the previous step. This statistical technique detects associations and oppositions existing between subjects and objects, measuring their contribution to the total inertia for each factor. The projection of the subjects and the objects onto the same set of factorial axes enables twodimensional graphs to be drawn which help to visualize the results (Teil, 1975). This statistical technique is very similar to a principal component factor analysis but for categorical data.

In order to conduct this statistical analysis, we need a matrix with the subjects as rows and the objects as columns. Here, the subjects will be our 28 dimensions, and the objects are the 41 papers. Therefore, the matrix is $28 \times 41$ with 1 in the cells where that paper contains that dimension and 0 where it does not.

The simultaneous representation of the results of both the subjects and the objects in a graphical form gives a clearer understanding of the detected associations and oppositions in the data. Following these recommendations, we employed the first and the second resulting factors, which represent more than half of the total inertia proportion $(54.3 \%)$. Using the first two factors, which represent the two most statistically important dimensions, we plotted the 28 dimensions using their scores from these two factors, which means that the proximity across them represents a thematic similarity. This means that, dimensions that are closer together tend to be frequently associated or share a contextual meaning while the opposite is true of distant dimensions. The result of this analysis is displayed in figure 3 .

Before proceeding with our analysis, we first turn briefly to the factors themselves. The first and second factors (axis $\mathrm{X}$ and $\mathrm{Y}$ on the plot) represent statistical solutions, but their meaning is open to interpretation. While we acknowledge other views are possible, we interpret the first factor (X-axis) as representing the notion of the construct's level of collaboration. From left to right (or high to low), one moves first from high collaborative dimensions to less collaborative ones. The second factor (Y-axis) represents the overall internal vs external focus of the construct. From bottom to top (or low to high), one moves from very internal dimensions to external ones.

Once we conducted the multiple correspondence factor analysis, we used the scores from the first two factors to conduct a cluster analysis. Cluster analysis is a collective term covering a wide variety of techniques for delineating natural groups or clusters in data sets. Two popular approaches to cluster analysis are hierarchical cluster analysis (Greenacre, 2008) and k-means (Jain, 2010). We conducted both types of cluster analysis for the data set. The results were the same; thus, additional validity was provided for our clustering analysis.

The best solution yielded seven different clusters. Therefore, we propose that the current 28 dimensions can be further grouped into seven major clusters. They are represented in figure 3. Once again, we point out that these clusters represent the major research clusters on how previous research has studied the measurement of the innovation culture construct. The main difference between figure 3 and figure 2 is that figure 2 shows all 28 dimensions uncovered in the literature review and plots them according to their presence and importance in the previous literature. Figure 3, on the other hand, shows how previous research has investigated these 28 dimen- 
sions, which dimensions have been investigated together, and which ones have not been investigated in the same research design. We will now briefly discuss each one of the seven clusters identified.

Cluster 1 "measuring innovation culture through employee characteristics": This cluster groups together eight different dimensions (failure acceptance, personality traits, workload pressure, resources, autonomy, risk-taking, organisational structure, and rewards system). This cluster has mainly core and generic dimensions. It primarily reflects work on measuring innovation culture through the employee's characteristics, such as their personality traits, autonomy on their jobs, allowing resources for innovation, avoids workload pressure, etc.

Cluster 2 "measuring innovation culture through the external orientation and strategy": This cluster groups nine dimensions, and is the one with the greatest number of dimensions (value orientation, first to market, teamwork, behaviour, strategic, product, future orientation, process, and management encouragement). This cluster has dimensions from all four quadrants that are evenly divided. It primarily reflects papers on how to measure innovation culture through the external orientation/focus of the company, the overall process, strategy, and behaviour of the company. This cluster, along with cluster 1 , represents more than $60 \%$ of all dimensions.

Cluster 3 "measuring innovation culture through communication": This cluster contains two dimensions (communication and infrastructure). Communication is a core dimension, while infrastructure is a minor one. It primarily reflects the work on how to measure innovation culture by relying on the level of internal communication and how infrastructure can affect the effectiveness of the communication within the company.

Cluster 4 "measuring innovation culture trough collaboration": This cluster groups together four dimensions (decision making, organisational learning, market orientation, and sharing). It contains two core, one generic, and one minor dimension. It reflects the work on how to measure innovation culture by the level of collaboration inside the company, operationalized through decision making, organisational learning, sharing, and the outside market orientation.

Cluster 5 "measuring innovation culture through change": This cluster groups two dimensions, willingness to change (niche) and implementation (minor). It reflects the research conducted on measuring innovation culture based on how eager the company is to change their processes, operations, etc. and implement new ideas.

Figure 3. Multiple correspondence factor analysis plot and cluster analysis.

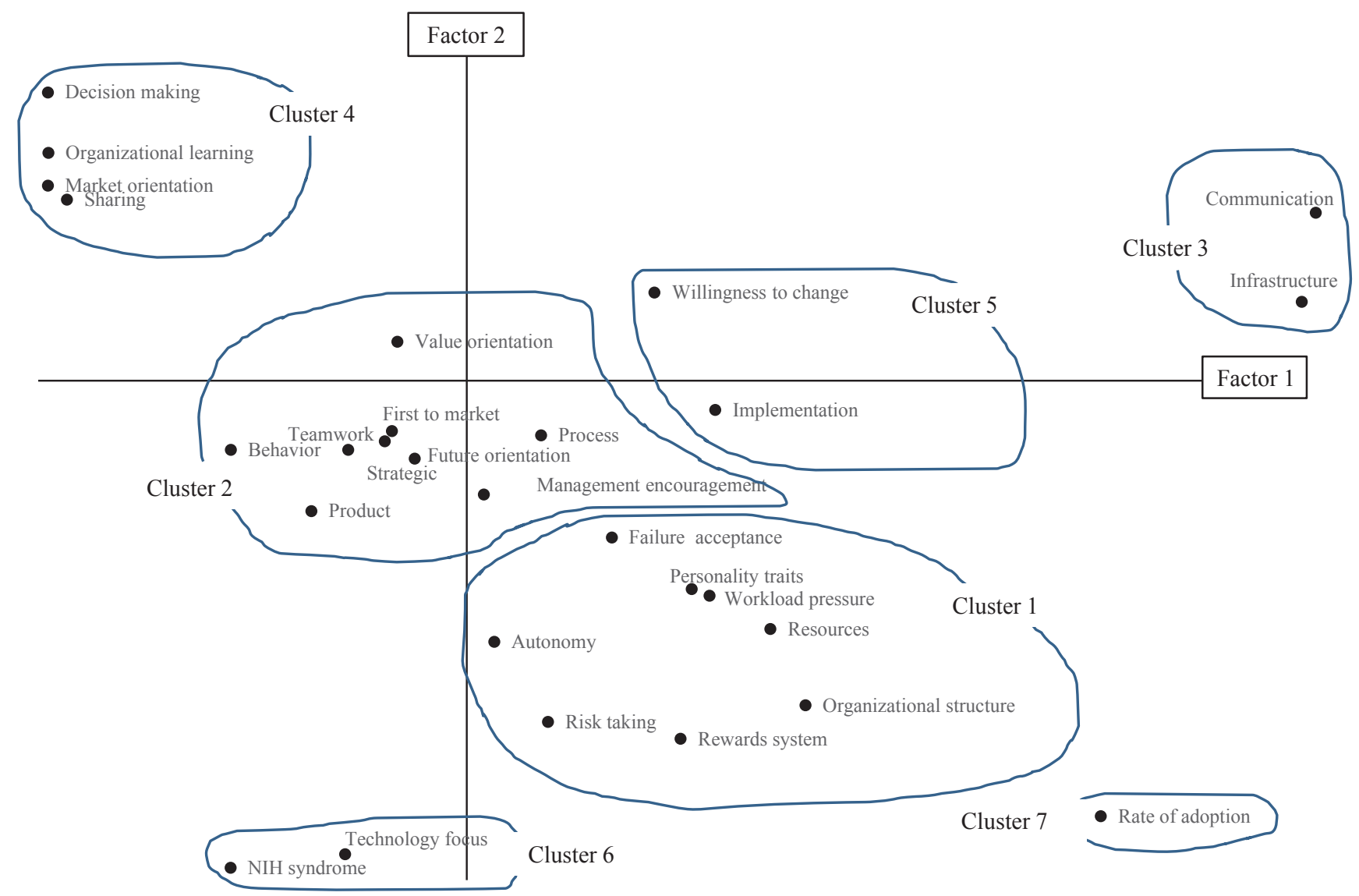


Cluster 6 "measuring innovation culture through technology": This cluster groups together two niche dimensions, technology focus and not invented here (NIH) syndrome. It reflects the work on how to measure innovation culture based on the level of technology employed by the company and how the NIH syndrome can decrease the positive perception of new technologies and, therefore, decrease the level of innovation culture.

Cluster 7 "measuring innovation culture trough adoption": Finally, cluster 7 groups one dimension, rate of adoption (niche). This mainly reflects how to measure innovation culture through how rapidly or slowly companies adopt new ideas and business processes.

\section{Discussion}

Scholars have been measuring innovation culture within organisations for more than 30 years. All this research has produced a rich but rather unorganised array of different dimensions for the construct. To the best of the authors' knowledge, this is the first attempt to offer a synthesis of the literature measuring this construct. We offer a robust, objective, complete, and precise view of how scholars have been measuring the innovation culture construct in the previous literature. Our results indicate that the innovation culture construct has been measured by 28 different dimensions. Furthermore, these 28 dimensions can be graphed along two dimensions: presence of the dimension in the whole literature and importance of the dimension within a single research project. From this analysis, our results show that the 28 dimensions can be visualized into a four-quadrant matrix: 1) core dimensions: those high in both importance and presence; 2) niche dimensions: those high in importance but relatively low in presence; 3) minor dimensions: those low in both importance and presence; and 4) generic dimension: those low in importance but high in presence in the literature.

By conducting a multiple correspondence factor analysis along with a cluster analysis, we were able to uncover the underlying clusters that group together these 28 dimensions and show that scholars have fundamentally measured innovation culture in seven different ways. Our data reveals that the 28 dimensions can be integrated into seven different clusters, which reflect the 7 main types of approaches that researchers have applied to measure the level of innovation culture of a company. We conclude that previous research in the field has measured innovation culture through employee characteristics, external orientation and strategy, internal communication, collaboration, willingness to change, the technology employed, and the adoption of new ideas.

We argue that this relevant construct needs consensus among researchers in the field. Therefore, based on our analyses and findings, we propose the following avenues for future research in order to advance scientific knowledge on this phenomenon.

\section{Future research}

Unification of the measurement of the construct: one of the main conclusions of our work is that the construct of innovation culture needs to be unified. Together with the present paper, we identified many different ways that researchers measure the construct; there were virtually no two papers that employed the same exact scale. Specifically, we identified 28 different dimensions and seven research clusters that involve them. There is a severe lack of consensus regarding the operational definition of the innovation culture construct. We strongly call for future research in this domain; the scholar community must have a robust, valid, and reliable measurements of the innovation culture construct. Some of the mixed results on this domain can be better addressed by having a valid measurement of the construct. Furthermore, more insightful research can be conducted by employing a thorough measure of the innovation culture. Future research can employ sophisticated statistical techniques along with multiple validity and reliability measures in order to offer a thorough measurement scale for this important construct in the field. We contribute to this literature by proposing that a truly valid and reliable measurement must include all 28 dimensions and integrate all 7 different approaches scholars have used to measure this construct.

Clear relationships across the dimensions: Our research shows unclear relationships across the whole spectrum of the innovation culture construct. We found the domain somewhat fuzzy regarding the interrelationships across the different dimensions. For example, it is unclear how the internal aspects (such as organisational learning, structure, communication, etc.) relate to the external aspects (such as market orientation, first to market, etc.). Another example of the unclarity of these dimensions is how the risk tolerance aspects (failure acceptance, risk-taking, willingness to change, NIH syndrome, etc.) influence the individual aspects or even the teamwork dynamics within the company. These are just a few examples of the unclear relationships across the whole domain of the innovation culture construct. Future research should explore such relationships in more detail.

Antecedents of the innovation culture: Some important questions remain in the field: What are the factors that drive innovation culture within a company? What are the factors that hinder innovation culture within a company? Even though there is a vast literature in this regard, it is still unclear how companies and managers can propitiate an innovation culture. We argue that this lack 
of knowledge can be attributed to an incomplete measure of the construct that has been used in previous research.

Consequences of the innovation culture: An innovation initiative can have many implications in the subcultures within a company (Ogbonna \& Harris, 2006). Therefore, future research should explore in more detail the outcomes of implementing an innovation culture within a company, not only in immediate financial and performance measures but also in the long-term.

More qualitative research: We found that there are very few qualitative papers on this topic. We argue that more qualitative research is needed in order to fully understand possible underlying mechanisms and contextual factors in this phenomenon.

Longitudinal research. In our review we could not find any longitudinal study on the topic of measuring the innovation culture construct. We argue that more longitudinal research is needed in the field in order to determine how the importance, presence, and clusters of these dimensions have evolved over time.

In summary, we provide the innovation management discipline with both a historical and relevant holistic view of one of its most important constructs: Innovation culture. We hope researchers build upon this research to keep developing more knowledge regarding how the innovation culture can foster innovations within a company, how can it be better operationalized, and how it relates to other important constructs. Advancing knowledge depends on consensus, on a field's understanding about what is, and what is not, important to it. In this paper, we have offered a comprehensive, detailed view of the measurement of the innovation culture construct, and we have shown its dimensions, organisation, and different ways scholars have operationalized it. In essence, we provide the innovation management community both a historical and contemporary view of one of their most important constructs, and by advancing an array of implications and observations, we also hope to guide where the field goes in the future.

\section{References}

Aghion, P. et al. (2005). Competition and innovation: An inverted U relationship. The Quarterly Journal of Economics, 120(5), 701-728. doi: 10.1007/s10842011-0123-4.

Ahmed, P. K. (1998). Culture and climate for innovation, European Journal of Innovation Management, 1(1), 30-43. doi: 10.1108/14601069810199131.

Apekey, T. A. et al. (2011). Room for improvement? Leadership, innovation culture and uptake of quality improvement methods in general practice. Journal of
Evaluation in Clinical Practice, 17(2), 311-318. doi: 10.1111/j.1365-2753.2010.01447.x.

Arad, S., Hanson, M. A., \& Schneider, R. J. (1997). A framework for the study of relationships between organisational characteristics and organisational innovation. Journal of Creative Behavior, 31(1), 42-58. doi: 10.1002/j.2162-6057.1997.tb00780.x.

Auh, S., \& Menguc, B. (2005). Top management team diversity and innovativeness: The moderating role of interfunctional coordination. Industrial Marketing Management, 34(3), 249-261. doi: 10.1016/j.indmarman.2004.09.005.

Avlonitis, G. J., Kouremenos, A., \& Tzokas, N. (1994). Assessing the Innovativeness of Organisations and its Antecedents: Project Innovstrat. European Journal of Marketing, 28(11), 5-28. doi: 10.1108/03090569410075812.

Baldridge, J. V., \& Burnham, R. A. (1975). Organisational innovation: Individual, organisational, and environmental impacts, Administrative Science Quarterly, 20, 165-176. doi: 10.2307/2391692.

Brettel, M., \& Cleven, N. J. (2011). Innovation culture, collaboration with external partners and NPD performance. Creativity and Innovation Management, 20(4), 253-272. doi: 10.1111/j.1467-8691.2011.00617.x.

Calantone, R. J., Cavusgil, S. T., \& Zhao, Y. (2002). Learning orientation, firm innovation capability, and firm performance. Industrial Marketing Management, 31(6), 515-524. doi: 10.1016/S0019-8501(01)00203-6.

Capon, N. et al. (1992). Profiles of Product Innovators Among Large U.S. Manufacturers. Management Science, 38(2), 157-169. doi: 10.1287/mnsc.38.2.157.

Chandler, G. N., Keller, C., \& Lyon, D. W. (2000). Unraveling the Determinants and Consequences of an Innovation-Supportive Organisational Culture. Entrepreneurship Theory and Practice, 25(1), 59-76. doi: 10.1177/104225870002500106.

Chatzoglou, P., \& Chatzoudes, D. (2017). The role of innovation in building competitive advantages: an empirical investigation. European Journal of Innovation Management, EJIM-02-2017-0015. doi: 10.1108/ EJIM-02-2017-0015.

Coad, A., \& Rao, R. (2008). Innovation and firm growth in high-tech sectors: A quantile regression approach. Research Policy, 37(4), 633-648. doi: 10.1016/j.respol.2008.01.003.

Crossan, M. M., \& Apaydin, M. (2010). A Multi-Dimensional Framework of Organisational Innovation: A Systematic Review of the Literature. Journal of Management Studies. Blackwell Publishing Ltd, 47(6), 1154-1191. doi: 10.1111/j.1467-6486.2009.00880.x. 
Daft, R. L. (1978). A Dual-Core Model of Organisational Innovation. Academy of Management Journal, 21(2), 193-210. doi: 10.2307/255754.

Damanpour, F. (1991). Organisational Innovation: A Meta-Analysis of Effects of Determinants and Moderators, Academy of Management Journal, 34(3). 555590. doi: 10.2307/256406.

Deshpande, R., Farley, J. U., \& Webster, F. E. (1993). Corporate Culture, Customer Orientation, and Innovativeness in Japanese Firms: A Quadrad Analysis. Journal of Marketing, 57(1), 23-37. doi: 10.2307/1252055.

Didero, M. et al. (2008). Differences in innovation culture across Europe. Culture, (January 2006), 1-36.

Dobni, C. B. (2008). Measuring innovation culture in organisations: The development of a generalized innovation culture construct using exploratory factor analysis. European Journal of Innovation Management, 11(4), 539-559. doi: 10.1108/14601060810911156.

Dombrowski, C. et al. (2007). Elements of innovative cultures. Knowledge and Process Management, 14(3), 190-202. doi: 10.1002/kpm.279.

Drucker, P. (1986). Innovation and entrepreneurship: Practices and principles. Journal of continuing higher education, 34(1), 2-23. doi: 10.1080/07377366.1986.10401060.

Edmondson, A. C., \& Mcmanus, S. E. (2007). Methodological fit in management field research. Academy of Management Review, 32(4), 1155-1179. doi: 10.5465/ AMR.2007.26586086.

Eisenberger, R., Fasolo, P., \& Davis-LaMastro, V. (1990). Perceived Organisational Support and Employee Diligence, Commitment, and Innovation. Journal of Applied Psychology, 75(1), 51-59. doi: 10.1037/00219010.75.1.51.

Greenacre, M. (2008). Hierarchical cluster analysis. Correspondence Analysis and Related Methods. Bulletin of Sociological Methodology.

Herzog, P. (2008). Open and closed innovation: Different cultures for different strategies. Springer Science \& Business Media.

Hult, G. T. M., Hurley, R. F., \& Knight, G. A. (2004). Innovativeness: Its antecedents and impact on business performance, Industrial Marketing Management, 33(5), 429-438. doi: 10.1016/j.indmarman.2003.08.015.

Hurley, R. F., \& Hult, G. T. M. (1998). Innovation, Market Orientation, and Organisational Learning: An Integration and Empirical Examination, Journal of Marketing, 62(3), 42-54. doi: 10.2307/1251742.

Hurt, H. T., Joseph, K., \& Cook, C. D. (1977). Scales for the Measurement of Innovativeness. Human Communication Research, 4(1), 58-65. doi: 10.1111/j.14682958.1977.tb00597.x.
Jacques, E. (1951). The Changing Culture of a Factory (Industrial Relations). Tavistock Publications.

Jain, A. K. (2010). Data clustering: 50 years beyond K-means. Pattern Recognition Letters. doi: 10.1016/j. patrec.2009.09.011.

Jin, Z., Navare, J., \& Lynch, R. (2019). The relationship between innovation culture and innovation outcomes: exploring the effects of sustainability orientation and firm size. $R \& D$ Management. Blackwell Publishing Ltd, 49(4), 607-623. doi: 10.1111/radm.12351.

Leavy, B. (2005). A leader's guide to creating an innovation culture. Strategy \& Leadership, 33(4), 38-45. doi: 10.1108/10878570510608031.

Linke, A., \& Zerfass, A. (2011). Internal communication and innovation culture: developing a change framework. Journal of Communication Management, 15(4), 332-348. doi: 10.1108/13632541111183361.

Martín-de Castro, G. et al. (2013). The moderating role of innovation culture in the relationship between knowledge assets and product innovation. Technological Forecasting and Social Change, 80(2), 351-363. doi: 10.1016/j.techfore.2012.08.012.

Martín-Martín, A. et al. (2018). Google Scholar, Web of Science, and Scopus: A systematic comparison of citations in 252 subject categories. Journal of Informetrics, 12(4), 1160-1177. doi: 10.1016/j.joi.2018.09.002.

Martins, E. C., \& Terblanche, F. (2003). Building organisational culture that stimulates creativity and innovation. European Journal of Innovation Management, 6(1), 64-74. doi: 10.1108/14601060310456337.

McLaughlin, P., Bessant, J., \& Smart, P. (2008). Developing an organisational culture to facilitate radical innovation. International Journal of Technology Management, 44(3/4), 298. doi: 10.1504/IJTM.2008.021041.

McLean, L. D. (2005). Organisational culture's influence on creativity and innovation: A review of the literature and implications for human resource development. Advances in Developing Human Resources, 7(2), 226-246. doi: 10.1177/1523422305274528.

Michaelis, T. L., Aladin, R., \& Pollack, J. M. (2018). Innovation culture and the performance of new product launches: A global study. Journal of Business Venturing Insights, 9, 116-127. doi: 10.1016/j. jbvi.2018.04.001.

Miozzo, M., \& Ramirez, M. (2003). Services innovation and the transformation of work: The case of UK telecommunications. New Technology, Work and Employment, 18(1), 62-79. doi: 10.1111/1468-005X.00111.

Mohr, L. B. (1969). Determinants of innovation in organisations. The American Political Science Review, 63(1), 111-126. doi: 10.2307/1954288.

Naranjo-Valencia, J. C., Jiménez-Jiménez, D., \& Sanz-Valle, R. (2011). Innovation or imitation? The role of organisational culture. Management Decision, 49(1), 55-72. doi: 10.1108/00251741111094437. 
Nestle, V. et al. (2019). Establishing open innovation culture in cluster initiatives: The role of trust and information asymmetry. Technological Forecasting and Social Change, 146, 563-572. doi: 10.1016/j.techfore.2018.06.022.

O'Cass, A., \& Viet Ngo, L. (2007). Market orientation versus innovative culture: Two routes to superior brand performance. European Journal of Marketing, 41(7/8), 868-887. doi: 10.1108/03090560710752438.

Ogbonna, E., \& Harris, L. C. (2006). Organisational culture in the age of the Internet: An exploratory study. New Technology, Work and Employment. 20, 2-18. doi: 10.1111/j.1468-005X.2006.00170.x.

Olmos-Peñuela, J. et al. (2017). Strengthening SMEs' innovation culture through collaborations with public research organisations. Do all firms benefit equally? European Planning Studies. Routledge, 25(11), 2001 2020. doi: 10.1080/09654313.2017.1279592.

Padilha, C. K., \& Gomes, G. (2016). Innovation culture and performance in innovation of products and processes: A study in companies of textile industry. RAI Revista de Administração e Inovação. Emerald, 13(4), 285-294. doi: 10.1016/j.rai.2016.09.004.

Pallas, F. et al. (2013). Investigating organisational innovativeness: Developing a multidimensional formative measure. International Journal of Innovation Management, 17(04), 1-41. doi: 10.1142/ S1363919613500096.

Porter, M. E. (2008). Competitive advantage: Creating and sustaining superior performance. Simon and Schuster.

Schein, E. H. (1990). Organisational culture. American Psychologist, 45(2), 109-119. doi: 10.1037/0003066X.45.2.109.

Schreier, M., Fuchs, C., \& Dahl, D. W. (2012). The Innovation Effect of User Design: Exploring Consumers' Innovation Perceptions of Firms Selling Products Designed by Users, Journal of Marketing, 76(5), 18-32. doi: 10.1509/jm.10.0462.

Scott, S. G., \& Bruce, R. A. (1994). Determinants of innovative behavior: A path model of individual innovation in the workplace. Academy of Management Journal, 37(3), 580-607. doi: 10.2307/256701.
Sharifirad, M. S., \& Ataei, V. (2012). Organisational culture and innovation culture: Exploring the relationships between constructs. Leadership \& Organisation Development Journal, 33(5), 494-517. doi: 10.1108/01437731211241274.

Siguaw, J. A., Simpson, P. M., \& Enz, C. A. (2006). Conceptualizing innovation orientation: A framework for study and integration of innovation research. Journal of Product Innovation Management, 23(6), 556-574. doi: 10.1111/j.1540-5885.2006.00224.x.

Simonson, M. (2000). Personal innovativeness, perceived organisational innovativeness, and computer anxiety: Updated scales. Quarterly Review of Distance Education, 1(1), 69-76.

Spiggle, S. (1994). Analysis and interpretation of qualitative data in consumer research. Journal of Consumer Research, 21(3), 491-503.

Subramanian, A., \& Nilakanta, S. (1996). Organisational innovativeness: Exploring the relationship between organisational determinants of innovation, types of innovations, and measures of organisational performance. Omega, 24(6), 631-647. doi: 10.1016/S03050483(96)00031-X.

Teil, H. (1975). Correspondence factor analysis: An outline of its method. Journal of the International Association for Mathematical Geology. doi: 10.1007/ BF02080630.

Unger, B. N., Rank, J., \& Gemünden, H. G. (2014). Corporate innovation culture and dimensions of project portfolio success: The moderating role of national culture. Project Management Journal, 45(6), 38-57. doi: $10.1002 / \mathrm{pmj}$.

Wang, C. L., \& Ahmed, P. K. (2004). The development and validation of the organisational innovativeness construct using confirmatory factor analysis. European Journal of Innovation Management, 7(4), 303-313. doi: 10.1108/14601060410565056.

Webster, J., \& Wing-Fai, L. (2017). Introduction: Creativity, knowledge, and innovation in virtual work. New Technology, Work and Employment, 32(1), 1-11. 